\title{
PRE AND POST CONTROL OF WEEDY RICE AND SELECTED RICE WEEDS WITH PREMIX OF IMAZAPIC AND IMAZAPYR AT DIFFERENT RATIOS
}

\author{
DILIPKUMAR MASILAMANY ${ }^{*}$, ERWAN SHAH SHARI ${ }^{1}, \mathrm{NG}_{\text {LEE CHUEN }}^{2}, \mathrm{CHUAH}^{\mathrm{T}} \mathrm{CHE} \mathrm{SENG}^{*}$ \\ and BHAGIRATH SINGH CHAUHAN ${ }^{4}$ \\ ${ }^{1}$ Rice Research Centre, Malaysian Agricultural Research and Development Institute (MARDI), \\ MARDI Seberang Perai, 13200 Kepala Batas, Pulau Pinang, Malaysia \\ ${ }^{2}$ School of Food Science and Technology, Universiti Malaysia Terengganu, \\ 21300 Kuala Terengganu, Terengganu, Malaysia \\ ${ }^{3}$ Faculty of Plantation and Agrotechnology, Universiti Teknologi MARA, \\ UiTM Arau, 02600 Arau, Perlis, Malaysia \\ ${ }^{4}$ The Centre for Crop Science, Queensland Alliance for Agriculture and Food Innovation (QAAFI) \\ and School of Agriculture and Food Sciences (SAFS), The University of Queensland, \\ Gatton 4343, Queensland, Australia \\ *E-mail: dilip@mardi.gov.my
}

Accepted 4 October 2021, Published online 31 December 2021

\begin{abstract}
Field experiments were conducted in the rice fields of the Malaysian Agricultural Research and Development Institute in 2018 and 2019, to determine the efficacy of two commercial premix herbicides consisting of imazapic and imazapyr at 70:30 (formulation 1) and 30:70 (formulation 2) applied singly or in sequence for control of weedy rice and other rice weeds. Formulation 1 was applied as PRE at the 0 to 1-leaf stage of weedy rice while formulation 2 was applied as POST at the 3 to 4-leaf stage of weedy rice. Formulation 1 applied PRE at $150 \mathrm{~g}$ ai ha ${ }^{-1}$ with or without sequential application of formulation 2 applied POST at 75 or $150 \mathrm{~g}$ ai ha- ${ }^{-1}$ provided complete inhibition of weedy rice. The same rate of formulation 1 applied PRE highly reduced weed density and dry weight of Monochoria vaginalis (99\%) and Fimbristylis quinquangularis $(93 \%)$ as compared to weedy check plots. Formulation 2 applied POST at $150 \mathrm{~g}$ ai ha ${ }^{-1}$ providing lower weed density and dry weight reduction of weedy rice (59 to 65\%), M. vaginalis (80 to 81\%), and F. quinquangularis (56 to $64 \%$ ) as compared to those observed in formulation 1 applied PRE at $150 \mathrm{~g}$ ai ha ${ }^{-1}$. These results suggest that although formulations 1 and 2 share the same active ingredients, excellent control of weedy rice and rice weeds could only be achieved with PRE application of formulation 1 at $150 \mathrm{~g}$ ai ha ${ }^{-1}$.
\end{abstract}

Key words: Clearfield ${ }^{\circledR}$ rice, herbicide formulation, herbicide-tolerant rice, imidazolinone herbicide, weedy rice

\section{INTRODUCTION}

Malaysian farmers have long-adopted the wet-seeded rice (Oryza sativa L.) culture since 1980, wherein about $90 \%$ of the rice fields in the country are now planted with this method, and the rest using traditional transplanting (Dilipkumar et al., 2020). The wet-seeded rice system faces a major challenge for further adoption as weedy rice (Oryza spp.), infestation presents a direct obstacle to crop production (Chauhan, 2012). However, the introduction of imidazolinone-resistant rice

\footnotetext{
* To whom correspondence should be addressed.
}

technology to Malaysia in 2010 has benefitted the rice industry by increasing crop yield in fields heavily infested with weedy rice (Azmi et al., 2012). Imidazolinone-resistant rice was developed through chemical mutagenesis and traditional breeding (Rajguru et al., 2005). A point mutation in imidazolinone-resistant rice is targeted to the acetolactate synthase (ALS) enzyme gene, which is the binding site of imidazolinone herbicides.

Imidazolinones are chiral herbicides, comprised of two enantiomers with differential herbicidal activity (Ramezani et al., 2010). Imazapyr, imazapic, imazaquin, imazamox, imazethapyr, and imazamethabenz-methyl are the synthetic compounds 
clustered under imidazolinone herbicides. The selection of an imidazolinone herbicide formulation depends on the country's cultural practices, biotic and abiotic factors, as well as any relevant regulations and policies. For instance, Italy officially marketed imazamox for imidazolinone-resistant rice cultivation (Scarabel et al., 2012), while a premix formulation of imazethapyr and imazapic was widely used in the imidazolinone-resistant rice system in Brazil and Uruguay (Kraemer et al., 2009). In the southern USA, imazethapyr is used as the base component of various site-specific, pre-emergence, and post-emergence weed management programs for imidazolinone-resistant rice (Steele et al., 2002; Webster et al., 2012). A premix formulation that contains imazapic and imazapyr, is the officially registered herbicide for the imidazolinone-resistant rice system in Malaysia (Azmi et al., 2012).

Imazapic \{2-[(RS)-4-isopropyl-4-methyl-5-oxo-2imidazolin-2-yl]-5-methylnicotinic acid $\}$ and imazapyr \{2-[(RS)-4-isopropyl-4-methyl-5-oxo-2-imidazolin-2yl]nicotinic acid \} can both be used as PRE or POST herbicides that control many grass and broadleaf weeds (Ulbrich et al., 2005). However, imazapic is more effective when applied as a PRE herbicide as it provides residual control of germinating weeds (Mangold et al., 2013). The premix formulation used in an imidazolinone-resistant rice system in Malaysia contains 70\% imazapic and 30\% imazapyr (hereafter referred to as formulation 1), hence it is recommended to spray at 0 to 7 days after sowing (DAS) (Dilipkumar et al., 2018). A recent survey in imidazolinone-resistant rice fields found that several Malaysian rice farmers ignored the stewardship guidelines by spraying formulation 1 as a POST herbicide which could cause the escape of weedy rice and result in leakage of the resistance trait from imidazolinone-resistant rice to weedy rice by natural hybridization (Dilipkumar et al., 2021). Azmi et al. (2012) reported that formulation 1 sprayed in standing water conditions can reduce the efficacy of the herbicide, eventually leading to weedy rice escapees. Generally, in the wet-seeded rice culture, fields are flooded at 10 to 15 DAS. The recommended spraying window for formulation 1 is in line with this field requirement. However, under certain circumstances, formulation 1 application at the appropriate time becomes difficult when rice fields are prematurely flooded due to heavy rain or poorly-timed irrigation.

Taking these issues into consideration, a POST imidazolinone herbicide is vital for imidazolinoneresistant rice production in Malaysia. The reverse composition of formulation 1 which contains $30 \%$ imazapic and $70 \%$ imazapyr (hereafter referred to as formulation 2), is sprayed as POST herbicide in imidazolinone-resistant rice fields in Brazil (Sartori et al., 2013; Cassol et al., 2015). The efficacy of formulation 2 to control Malaysian weedy rice populations has not yet been explored. Furthermore, it is not clear if a POST application of formulation 2 following PRE application of formulation 1 will improve control of weedy rice and other rice weeds. Although formulation 1 and formulation 2 have the same active ingredients, different herbicide compositions applied PRE or POST may result in different weed control efficiency. Therefore, the present study was conducted to evaluate the effects of single and sequential application of two different commercial formulations of imazapic + imazapyr (formulation $1 \&$ formulation 2) at different application rates on the emergence and growth of weedy rice and other rice weeds.

\section{MATERIALS AND METHODS}

\section{Herbicide and plant materials}

Two commercial premix herbicides consisting of imazapic and imazapyr at 70:30 (formulation 1) and 30:70 (formulation 2) were provided by BASF (Malaysia) Pvt. Ltd., Shah Alam, Selangor, Malaysia. Weedy rice seeds were obtained from the Rice Genebank of the Malaysian Agricultural Research and Development Institute (MARDI), Seberang Perai, Pulau Pinang, Malaysia. The seeds were initially collected from a rice field in Paya Keladi, Pulau Pinang, Malaysia (5³3'43.2"N 100²9'30.9"E). Weedy rice seeds were examined to ensure the seeds had at least $95 \%$ germination; hence a simple bioassay test was performed under laboratory conditions and protocol as described by Hakim et al. (2011). Before the experiment started, the susceptibility of weedy rice to imidazolinone herbicide was confirmed by applying $150 \mathrm{~g} \mathrm{ha}^{-1}$ of formulation 1 on weedy rice seedlings at the 0 to 1 leaf stage. The screening procedure was carried out under glasshouse conditions following the method described by Dilipkumar et al. (2018).

\section{Experimental site}

Field studies were conducted in 2018 and 2019, at MARDI Seberang Perai, Pulau Pinang, Malaysia $\left(5^{\circ} 32^{\prime} 35.8^{\prime \prime} \mathrm{N} 100^{\circ} 27^{\prime} 51.6 " \mathrm{E}\right)$. The experimental area has no record of weedy rice infestation and has never been cultivated with Clearfield ${ }^{\circledR}$ rice. The soil texture is sandy clay loam ( $51 \%$ sand, $12 \%$ silt, \& $37 \%$ clay) with an organic matter content of $0.8 \%$ and a $\mathrm{pH}$ of 5.8. To avoid herbicide residue effects, the field experiment in 2019 was moved to an adjacent area with similar soil physicochemical properties (47\% sand, 14\% silt, \& 39\% clay with organic matter content of $0.8 \% \& \mathrm{pH}$ of 6.0 ).

\section{Experimental setup and data collection}

Since this study focused on the effect of herbicides on weedy rice; the imidazolinone resistant 
rice cultivar was not included in this test because the identical physiological characteristics between weedy rice and rice cultivars may cause difficulty during the data collection. Seedbed preparation consisted of one pass of a power tiller under dry soil conditions, one pass of a power tiller under flooded soil conditions, and subsequent leveling with a wooden plank. One hundred pre-germinated weedy rice seeds were hand-broadcasted onto a $2 \mathrm{~m}$ by $2 \mathrm{~m}$ plot under saturated soil conditions. Weedy rice density at this rate has been reported to cause rice yield loss of 60 to $80 \%$ (Azmi et al., 2005). Each plot was separated with an earth levee to avoid herbicide contamination from one plot to another. Fertilization consisted of N:P:K (17:20:10) at $140 \mathrm{~kg} \mathrm{ha}^{-1}$ and was applied at 12 days after sowing (DAS) and urea at $80 \mathrm{~kg} \mathrm{ha}^{-1}$ was added at 35 DAS. The experiment was arranged in a factorial completely randomized block design with five replications. Formulation 1 was applied as PRE at the 0 to the 1-leaf stage under saturated soil conditions while formulation 2 was applied as POST at the 3 to the 4-leaf stage under flooded soil conditions. These spraying windows were applied based on the label requirements of the respective herbicides. The label rates for both herbicides were $150 \mathrm{~g}$ ai ha ${ }^{-1}$; however, the half-rate was included in the treatment list to obtain a costeffective weed control in the sequential spray. The herbicide treatments were formulation 1 applied PRE at 75 or $150 \mathrm{~g}$ ai ha-1 $\mathrm{ha}^{-1}$ formulation 2 applied POST at 75 or $150 \mathrm{~g}$ ai ha ${ }^{-1}$; formulation 1 applied PRE at $75 \mathrm{~g}$ ai ha ${ }^{-1}$ followed by (fb.) formulation 2 applied POST at 75 or $150 \mathrm{~g}$ ai ha-1; formulation 1 applied PRE at $150 \mathrm{~g}$ ai ha- $\mathrm{fb}^{-1}$. formulation 2 at 75 or $150 \mathrm{~g}$ ai ha $\mathrm{ha}^{-1}$ and weedy check plot. A non-ionic surfactant was added to all treatments at $0.15 \%$ concentration (v/v). Herbicides were sprayed using a $\mathrm{CO}_{2}$-pressurized backpack sprayer fitted with a single flat-fan nozzle (Even Flat Spray Nozzles E; Lechler Spray Technology Pvt. Ltd., Malaysia). The sprayer was calibrated at $145 \mathrm{kPa}$ to deliver $200 \mathrm{~L} \mathrm{ha}^{-1}$ of spray solution. At 10 DAS or when the weedy rice achieved the 3-leaf stage, all plots were flooded at 5 to $6 \mathrm{~cm}$ height until the experiment was terminated. At 50 DAS, weed density and shoot dry weight were determined from a $1 \mathrm{~m}^{2}$ quadrat placed in the middle of each plot. Weeds were uprooted, washed with tap water, sun-dried, counted according to species, and separately oven-dried at $70^{\circ} \mathrm{C}$ for constant dry mass, and then weighed.

\section{Statistical analysis}

All data were subjected to two-way analysis of variance (ANOVA) using SPSS version 15.0 (SPSS Inc. Chicago, IL, USA). Data were combined over years because the ANOVA revealed no significant differences between years. The means were then separated using the Tukey test at the 5\% level of significance.

\section{RESULTS AND DISCUSSION}

The study was conducted under a naturally occurring population of mixed weed species, except for weedy rice. Across both years, there were nine different weed species observed at the experimental sites. However, only three dominant weed species were selected namely, weedy rice, Monochoria vaginalis (Burm. f.) C. Presl ex Kunth and Fimbristylis quinquangularis (Vahl) Kunth represent grass, broadleaf, and sedge weeds respectively.

\section{Weedy rice}

A significant interaction between formulations 1 and 2 on weedy rice biomass and density was found although both formulations contained the same active ingredients (Table 1). The single application of formulation 2 (70:30) applied POST at a full rate reduced the density and growth of weedy rice by $59 \%$ and $65 \%$, respectively, implying the failure of formulation 2 to provide good control of weedy rice. By contrast, formulation 1 (30:70) applied PRE at half label rate could reduce the density and biomass of weedy rice by more than $87 \%$, whereas complete control of weedy rice was achieved at the full label

Table 1. ANOVA results for formulation 1 and formulation 2 interactions on weed density and dry weight of weedy rice, Monochoria vaginalis, and Fimbristylis quinquangularis

\begin{tabular}{|c|c|c|c|c|c|c|}
\hline \multirow{3}{*}{$\begin{array}{l}\text { Sources of } \\
\text { variation }\end{array}$} & \multicolumn{3}{|c|}{ Weed density } & \multicolumn{3}{|c|}{ Weed dry weight } \\
\hline & $\begin{array}{l}\text { Weedy } \\
\text { rice }\end{array}$ & M. vaginalis & F. quinquangularis & $\begin{array}{l}\text { Weedy } \\
\text { rice }\end{array}$ & M. vaginalis & F. quinquangularis \\
\hline & \multicolumn{6}{|c|}{$P$ values } \\
\hline Formulation 1 (F1) & $<0.0001$ & $<0.0001$ & $<0.0001$ & $<0.0001$ & $<0.0001$ & $<0.0001$ \\
\hline Formulation 2 (F2) & 0.0014 & 0.0002 & 0.0043 & $<0.0001$ & $<0.0001$ & 0.0109 \\
\hline $\mathrm{F} 1{ }^{*} \mathrm{~F} 2$ & 0.0031 & $<0.0001$ & 0.0034 & $<0.0001$ & $<0.0001$ & 0.0499 \\
\hline
\end{tabular}

Formulation 1 (70\% imazapic + 30\% imazapyr) was applied as PRE when weedy rice was at 0 to the 1-leaf stage while formulation 2 (30\% imazapic $+70 \%$ imazapyr) was applied as POST when weedy rice was at the 3 to 4-leaf stage. 
Table 2. The influence of the single and sequential application of formulation 1 and 2 on the density and dry weight of weedy rice

\begin{tabular}{|c|c|c|c|}
\hline Formulation 1 & Formulation 2 & Density & Dry weight \\
\hline \multicolumn{2}{|c|}{ 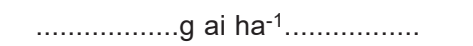 } & $\ldots \ldots$ plant $\mathrm{m}^{-2} \ldots \ldots$ & $\ldots . . g^{-2} \ldots \ldots$ \\
\hline- & - & $54.00 \mathrm{a}$ & 123.63 a \\
\hline - & 75 & $39.88 \mathrm{~b}$ & 59.75 b \\
\hline - & 150 & $22.38 \mathrm{c}$ & $43.88 b$ \\
\hline 75 & - & $7.13 \mathrm{~d}$ & $9.59 \mathrm{c}$ \\
\hline 75 & 75 & $5.50 \mathrm{~d}$ & $6.00 \mathrm{c}$ \\
\hline 75 & 150 & $1.38 \mathrm{~d}$ & $3.00 \mathrm{c}$ \\
\hline 150 & - & $0 d$ & $0 \mathrm{c}$ \\
\hline 150 & 75 & $0 \mathrm{~d}$ & $0 \mathrm{c}$ \\
\hline 150 & 150 & $0 \mathrm{~d}$ & $0 \mathrm{c}$ \\
\hline
\end{tabular}

Formulation 1 (70\% imazapic $+30 \%$ imazapyr) was applied as PRE when weedy rice was at 0 to the 1-leaf stage while formulation 2 (30\% imazapic $+70 \%$ imazapyr) was applied as POST when weedy rice was at the 3 to 4 -leaf stage. Mean within the same columns followed by the same lowercase letter indicates no significant difference at $P \leq 0.05$, as determined by a Tukey test. 75 and $150 \mathrm{~g}$ ai ha-1 are half and full label rates, respectively.

rate but no significant difference was found between these two application rates (Table 2). These results indicate the current recommended rate and spraying window of formulation 1 applied PRE alone is costeffective for management of weedy rice in the imidazolinone-resistant rice in Malaysia and efficient weedy rice control should begin as early as the seed germination stage and before the seedling stage. Similarly, Webster et al. (2012) reported that imidazolinone-resistant rice produced higher yields, which will produce higher returns and overall profits when the weeds are controlled at the 1 to 2-leaf stage.

Although a single spray of formulation 1 applied PRE at half label rate $\left(75 \mathrm{~g}_{\text {ai }} \mathrm{ha}^{-1}\right)$ could reduce weedy rice density by $87 \%$ and dry biomass $92 \%$ (Table 2), the weedy rice plants may not be controlled completely. Likewise, plots receiving the application of formulation 1 applied PRE at half rate (75 $\mathrm{g}$ ai ha- ${ }^{-1}$ ) followed by formulation 2 applied POST at half rate $(75 \mathrm{~g}$ ai ha-1 $)$ or full rate $(150 \mathrm{~g}$ ai ha-1) did not lead to further increased control of weedy rice (Table 2), indicating that there is no need to include formulation 2 applied POST as a sequential application. The weedy rice plants that survived after treatment may be able to escape and eventually produce seeds. This would favor the occurrence of outcrossing of weedy rice with cultivated rice (Merotto et al., 2016). Some cases report the failure to adhere to stewardship guidelines by spraying halflabel rates of formulation 1 in imidazolinone-resistant rice cultivation (Dilipkumar et al., 2021).

Nevertheless, a study conducted in Melaka, Malaysia reported a complete inhibition of weedy rice by formulation 1 applied PRE at 75 to $300 \mathrm{~g}$ ai ha- ${ }^{-1}$ (Mardiana et al., 2019). These findings show that different weedy rice biotypes in Malaysia may respond differently to imazapic plus imazapyr herbicide. A previous study has shown that eight weedy rice morphotypes could be distinguished based on a combination of traits such as awn presence/absence and hull color from 193 accessions collected in 17 locations across Malaysia (Sudianto et al., 2016). Therefore to avoid weedy rice biotype that escaped control measures, it is important to use the optimum rate of formulation 1 that stated in the stewardship guidelines of imidazolinone-resistant rice technology in Malaysia.

\section{Monochoria vaginalis}

$M$. vaginalis is the major problematic broadleaf weed in Malaysian rice fields (Juraimi et al., 2011). There was a significant interaction between formulation 1 and 2 on biomass and density of $M$. vaginalis. Formulation 2 applied POST at half rate could reduce the weed density and biomass by approximately $67 \%$. Increasing the application rate to full label rate could lead to $81 \%$ of weed reduction. Nevertheless, formulation 1 applied PRE at either half or full label rate provided a significant reduction of the density and biomass of $M$. vaginalis compared to those plots treated with formulation 2 applied POST at the full rate (Table 3). This indicates that formulation 1 applied PRE is more effective than formulation 2 applied POST in controlling broadleaf weed but complete control of $M$. vaginalis was not attained. Similarly, Oliveira et al. (2017) have also documented PRE-applied herbicides controlled broadleaf weeds better than POST-applied herbicides in soybean (Glycine max) field. On the other hand, the addition of formulation 2 applied POST at 75 or $150 \mathrm{~g}$ ai ha-1 in the sequential application of formulation 1 applied PRE at 75 or $150 \mathrm{~g}$ ai ha-1 did not improve the reduction of $M$. vaginalis density and biomass (Table 3 ). This finding suggests that sequential spray of formulation 2 applied POST after 
Table 3. The influence of the single and sequential application of formulations 1 and 2 on the density and dry weight of Monochoria vaginalis

\begin{tabular}{cccc}
\hline Formulation 1 & Formulation 2 & Density & Dry weight \\
\hline$\ldots \ldots \ldots \ldots \ldots$ g ai ha ${ }^{-1} \ldots \ldots \ldots \ldots \ldots$ & $\ldots \ldots$ plant $\mathrm{m}^{-2} \ldots \ldots$ & $\ldots \ldots \mathrm{g} \mathrm{m}^{-2} \ldots .$. \\
- & - & $601.25 \mathrm{a}$ & $677.12 \mathrm{a}$ \\
- & 75 & $212.63 \mathrm{~b}$ & $223.63 \mathrm{~b}$ \\
- & 150 & $111.75 \mathrm{c}$ & $133.00 \mathrm{~b}$ \\
75 & - & $26.25 \mathrm{~d}$ & $26.75 \mathrm{c}$ \\
75 & 75 & $17.00 \mathrm{~d}$ & $24.63 \mathrm{c}$ \\
75 & 150 & $19.13 \mathrm{~d}$ & $17.25 \mathrm{c}$ \\
150 & - & $7.13 \mathrm{~d}$ & $6.00 \mathrm{c}$ \\
150 & 75 & $8.88 \mathrm{~d}$ & $7.88 \mathrm{c}$ \\
150 & 150 & $4.13 \mathrm{~d}$ & $3.88 \mathrm{c}$ \\
\hline
\end{tabular}

Formulation 1 (70\% imazapic $+30 \%$ imazapyr) was applied as PRE when weedy rice was at 0 to the 1-leaf stage while formulation 2 (30\% imazapic $+70 \%$ imazapyr) was applied as POST when weedy rice was at the 3 to 4 -leaf stage. Mean within the same columns followed by the same lowercase letter indicates no significant difference at $P \leq 0.05$, as determined by a Tukey test.

75 and $150 \mathrm{~g}$ ai ha-1 ${ }^{-1}$ are half and full label rates, respectively.

Table 4. The influence of the single and sequential application of formulation 1 and 2 on the density and dry weight of Fimbristylis quinquangularis

\begin{tabular}{cccc}
\hline Formulation 1 & Formulation 2 & Density & Dry weight \\
\hline$\ldots \ldots \ldots \ldots \ldots .$. g ai ha ${ }^{-1} \ldots \ldots \ldots \ldots \ldots .$. & $\ldots \ldots$ plant $\mathrm{m}^{-2} \ldots$. & $\ldots . . \mathrm{g} \mathrm{m}^{-2} \ldots$. \\
- & - & $20.38 \mathrm{a}$ & $32.38 \mathrm{a}$ \\
- & 75 & $15.88 \mathrm{a}$ & $22.13 \mathrm{~b}$ \\
- & 150 & $9.00 \mathrm{~b}$ & $11.75 \mathrm{c}$ \\
75 & - & $4.38 \mathrm{bc}$ & $6.88 \mathrm{~cd}$ \\
75 & 75 & $5.63 \mathrm{bc}$ & $8.13 \mathrm{~cd}$ \\
75 & 150 & $2.63 \mathrm{c}$ & $6.00 \mathrm{~cd}$ \\
150 & - & $1.38 \mathrm{c}$ & $2.25 \mathrm{~d}$ \\
150 & 75 & $1.13 \mathrm{c}$ & $0.75 \mathrm{~d}$ \\
150 & 150 & $0.29 \mathrm{c}$ & $0.88 \mathrm{~d}$ \\
\hline
\end{tabular}

Formulation 1 (70\% imazapic $+30 \%$ imazapyr) was applied as PRE when weedy rice was at 0 to the 1-leaf stage while formulation 2 (30\% imazapic $+70 \%$ imazapyr) was applied as POST when weedy rice was at the 3 to 4 -leaf stage. Mean within the same columns followed by the same lowercase letter indicates no significant difference at $P \leq 0.05$, as determined by a Tukey test.

75 and $150 \mathrm{~g}$ ai ha-1 are half and full label rates, respectively.

application of formulation 1 applied PRE fails to control the weed that has escaped from the control of formulation 1 .

\section{Fimbristylis quinquangularis}

A significant interaction between formulation 1 and formulation 2 was noted on biomass and density of Fimbristylis quinquangularis. Formulation 2 applied POST at half rate of 75 ai ha ${ }^{-1}$ was able to reduce the dry weight of $F$. quinquangularis by $32 \%$ but it was not effective to reduce the weed density significantly. The increase of application rate to full label rate of $150 \mathrm{~g}$ ai ha ${ }^{-1}$ could further increase the reduction of the weed density and dry weight by 56 and $64 \%$, respectively (Table 4). Similar to $M$. vaginalis, increased control of weedy rice (Table 2), indicating that there is no need to include formulation
2 applied POST as a sequential application. The weedy rice plants survive between the half and full label rate. Application of formulation 1 applied PRE following formulation 2 applied at 75 or $150 \mathrm{~g}$ ai ha $^{-1}$ did not help to improve control of $F$. quinquangularis (Table 4). This result clearly shows that effective management of $F$. quinquangularis can be achieved by inhibiting seed germination or seedling emergence by spraying formulation 1 applied PRE. Begum et al. (2008) also suggested that $F$. quinquangularis can be managed successfully if control measures are taken early in the life cycle of the plant.

Despite the current issue of imidazolinoneresistant weedy rice in Malaysia (Dilipkumar et al., 2018), data from the present study shows that a single application of formulation 1 applied PRE at 150 
$\mathrm{g}$ ai ha-1 controlled imidazolinone-susceptible weedy rice and other important weed species effectively whereas a single application of formulation 2 applied POST at $150 \mathrm{~g}$ ai ha ${ }^{-1}$ failed to provide satisfactory control of the weedy rice and other rice weeds. Although formulation 1 and formulation 2 share the same active ingredients, the high imazapic composition in formulation 1 applied PRE could lead to the early inhibition of weed growth, eventually providing excellent weed control. This is the first study that assesses the efficacy of formulation 2 applied POST in Malaysia. Based on the results obtained, formulation 2 applied POST has a high potential to be replaced with formulation 1 applied PRE only after revising the rate. Therefore, further studies are needed to corroborate present findings and to explore the efficacy of formulation 2 (imazapic:imazapyr at 30:70) in the imidazolinoneresistant rice system in Malaysia.

\section{ACKNOWLEDGEMENTS}

This research was partially funded by the MARDIBASF collaboration project on the development of a local rice variety tolerant to the imidazolinone herbicide. No conflicts of interest have been declared.

\section{REFERENCES}

Azmi, M., Abdullah, M.Z. \& Muhamad, H. 2005. Weedy rice (padi angin): A real threat to rice industry and farmers, in: 4th National Seed Symposium of the Malaysian Association of Seed Technologists (MAST). Putrajaya, Malaysia, pp. 109-112.

Azmi, M., Azlan, S., Yim, K.M., George, T.V.\& Chew, S.E. 2012. Control of weedy rice in direct-seeded rice using the Clearfield production system in Malaysia. Pakistan Journal of Weed Science Research, 18: 49-53.

Begum, M., Juraimi, A.S., Amartalingam, R., SyedRatan, S.O. \& Azmi, M. 2008. Growth and development of Fimbristylis miliacea (L.) Vahl. Biotropia, 15(1): 1-11.

Cassol, G.V., de-Avila, L.A., Zemolin, C.R., Piveta, A., Agostinetto, D. \& Merotto-Júnior, A. 2015. Sensitivity of imidazolinone-resistant red rice (Oryza sativa L.) to glyphosate and glufosinate. Ciência Rural, 45: 1557-1563.

Chauhan, B.S. 2012. Weedy rice (Oryza sativa) II. Response of weedy rice to seed burial and flooding depth. Weed Science, 60(3): 385-388.
Dilipkumar, M., Ahmad-Hamdani, M.S., Rahim, H., Chuah, T.S. \& Burgos, N.R. 2021. Survey on weedy rice (Oryza sativa) management practice and adoption of Clearfield rice technology in Peninsular Malaysia. Weed Science, 69(5): 558564.

Dilipkumar, M., Burgos, N.R., Chuah, T.S. \& Ismail, S. 2018. Cross-resistance to imazapic and imazapyr in a weedy rice (Oryza sativa) biotype found in Malaysia. Planta Daninha, doi: 36 10.1590/S0100-83582018360100058.

Dilipkumar, M., Chuah, T.S., Goh, S.S. \& Ismail, S. 2020. Weed management issues, challenges, and opportunities in Malaysia. Crop Protection, 134: 104347.

Hakim, M.A., Juraimi, A.S., Hanafi, M.M., Selamat, A., Ismail, M.R. \& Karim, S.M.R. 2011. Studies on seed germination and growth in weed species of rice field under salinity stress. Journal of Environmental Biology, 32(5): 529-536.

Juraimi, A.S., Muhammad-Saiful, A.H., Uddin, M.K., Anuar, A.R. \& Azmi, M. 2011. Diversity of weed communities under different water regimes in Bertam irrigated direct seeded rice field. Australian Journal of Crop Science, 5(5): 595 604.

Kraemer, A.F., Marchesan, E., Grohs, M., de-Avila, L.A., Machado, S.L.O., Zanella, R., Massoni, P.F.S. \& Sartori, G.M.S. 2009. Imazethapyr leaching in rice paddy soil under two tillage systems. Ciência Rural, 39: 1660-1666.

Mangold, J., Parkinson, H., Duncan, C., Rice, P., Davis, E. \& Menalled, F. 2013. Downy brome (Bromus tectorum) control with imazapic on Montana grasslands. Invasive Plant Science and Management, 6: 554-558.

Mardiana, J.K., Bajrai, F.S.M., Muhamad-Safwan, I. \& Ismail, B.S. 2019. Effect of Onduty herbicide on weed populations and rice yields in selected rice fields, Melaka, Malaysia. Sains Malaysiana, 48(11): 2355-2365.

Merotto, A., Goulart, I.G., Nunes, A., Kalsing, A., Markus, C., Menezes, V. \& Wander, A. 2016. Evolutionary and social consequences of introgression of non-transgenic herbicide resistance from rice to weedy rice in Brazil. Evolutionary Applications, 9: 837-846.

Oliveira, M.C., Feist, D., Eskelsen, S., Scott, J.E. \& Knezevic, S.Z. 2017. Weed control in soybean with preemergence- and postemergence-applied herbicides. Crop Forage Turfgrass Management, 3(1): 1-7.

Rajguru, S.N., Burgos, N.R., Shivrain, V.K. \& Stewart, J.M.D. 2005. Mutations in the red rice ALS gene associated with resistance to imazethapyr. Weed Science, 53: 567-577. 
Ramezani, M.K., Oliver, D.P., Kookana, R.S., Lao, W., Gill, G. \& Preston, C. 2010. Faster degradation of herbicidally-active enantiomer of imidazolinones in soils. Chemosphere, 79(11): 1040-1045.

Sartori, G.M.S., Marchesan, E., Azevedo, C.F., Filho, A.C., Roso, R., Coelho, L.L. \& Oliveira, M.L. 2013. Effects of irrigated rice sowing season and imazapyr + imazapic time of application on rice grain yield and red rice management. Planta Daninha, 31(3): 631-644.

Scarabel, L., Cenghialta, C., Manuello, D. \& Sattin, M. 2012. Monitoring and management of imidazolinone-resistant red rice (Oryza sativa L., var. sylvatica) in Clearfield ${ }^{\circledR}$ Italian paddy rice. Agronomy, 2: 371-383.

Steele, G.L., Chandler, J.M. \& Mccauley, G.N. 2002. Control of red rice (Oryza sativa) in imidazolinone-tolerant rice (O. sativa). Weed Technology, 16(3): 627-630.
Sudianto, E., Neik, T.X., Tam, S.M., Chuah, T.S., Idris, A.A., Olsen, K.M. \& Song, B. 2016. Morphology of Malaysian weedy rice (Oryza sativa): Diversity, origin and implications for weed management. Weed Science, 64(3): 501-512.

Ulbrich, A.V., Souza, J.R.P. \& Shaner, D. 2005. Persistence and carryover effect of imazapic and imazapyr in Brazilian cropping systems. Weed Technology, 19(4): 986-991.

Webster, E.P., Carlson, T.P., Salassi, M.E., Hensley, J.B. \& Blouin, D.C. 2012. Imazethapyr plus residual herbicide programs for imidazolinoneresistant rice. Weed Technology, 26(03): 410-416. 
